\title{
A case of severe flare reaction observed in HLA B27 associated acute anterior uveitis
}

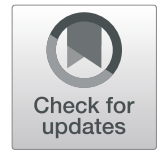

Jae-Ik Kim ${ }^{1,2}$ and Choul Yong Park ${ }^{1,2^{*}}$

\begin{abstract}
Background: Anterior chamber flare reaction refers to the light reflection from the protein in aqueous humor. We report a case of very severe flare reaction observed in human leukocyte antigen (HLA)- B27 associated acute anterior uveitis (AAU).

Case presentation: An age 43 male patient visited the uveitis clinic complaining of decreased visual acuity in the right eye which developed 1 week before. The detailed ophthalmic examination revealed very severe flare reaction in the anterior chamber with diffuse conjunctival hyperemia in the right eye. Pupil margin and iris details were barely observable. Oral prednisolone $20 \mathrm{mg}$ daily with topical 1\% prednisolone acetate (Pred Forte, Allergan, CA) every $2 \mathrm{~h}$ and $1 \%$ topical cyclopentolate (Cyclogyl, Alcon, TX) three times daily were immediately prescribed. The next day, the flare reaction of the right eye decreased significantly and inflammatory cells in the anterior chamber were visible. Detailed fundus examination revealed no inflammatory signs on the retina and ciliary body. Later, the blood test revealed positive HLA B27 and autoantibodies against lupus anticoagulant with mild elevation of C reactive protein. There were no signs for ankylosing spondylitis. Continued treatment and tapering of topical $1 \%$ prednisolone acetate for 4 weeks led to the complete resolution of the anterior uveitis.
\end{abstract}

Conclusions: We experienced HLA-B27 AAU with the feature of a very severe flare reaction. Conventional uveitis treatment was successful to acquire the complete resolution of the inflammation.

Keywords: Flare, HLA-B27, Acute uveitis, AAU, Immune

\section{Background}

Anterior chamber flare reaction refers to the light reflection from the protein in aqueous humor [1]. In the inflammatory situation, the breakdown of blood ocular barrier results in increased vascular permeability of the iris and ciliary body vessels and leakage of fibrin, cytokines and other proteins [2]. Flare reaction is easily detectable using a slit lamp biomicroscopy. And laser flare photometry enables an objective quantification of the flare reaction [3, 4]. Measurement of the flare reaction is valuable for the initial diagnosis and monitoring of

\footnotetext{
*Correspondence: oph0112@gmail.com

'Department of Ophthalmology, Dongguk University, Ilsan Hospital, 814, Siksadong, Ilsan-dong-gu, Goyang, Gyunggido 410-773, South Korea

${ }^{2}$ Sensory Organ Research Center, Dongguk University, Goyang, South Korea
}

treatment of intraocular inflammation including various types of uveitis $[2,4-8]$.

In this case report, we describe a very severe flare reaction observed in human leukocyte antigen (HLA)- B27 associated acute anterior uveitis (AAU).

\section{Case presentation}

An age 43 male patient visited our uveitis clinic complaining of decreased visual acuity in the right eye. He had a history of anterior uveitis treatment of the right eye 13 years before and of the left eye 8 years before. The current episode developed 1 week before and he was prescribed topical $0.1 \%$ fluorometholone eyedrops, four times daily from the local eye clinic. On the day of the visit, he experienced acute deterioration of vision of the right eye from the early morning wakening

C C The Author(s). 2020 Open Access This article is licensed under a Creative Commons Attribution 4.0 International License, which permits use, sharing, adaptation, distribution and reproduction in any medium or format, as long as you give appropriate credit to the original author(s) and the source, provide a link to the Creative Commons licence, and indicate if changes were made. The images or other third party material in this article are included in the article's Creative Commons licence, unless indicated otherwise in a credit line to the material. If material is not included in the article's Creative Commons licence and your intended use is not permitted by statutory regulation or exceeds the permitted use, you will need to obtain permission directly from the copyright holder. To view a copy of this licence, visit http://creativecommons.org/licenses/by/4.0/. The Creative Commons Public Domain Dedication waiver (http://creativecommons.org/publicdomain/zero/1.0/) applies to the data made available in this article, unless otherwise stated in a credit line to the data. 

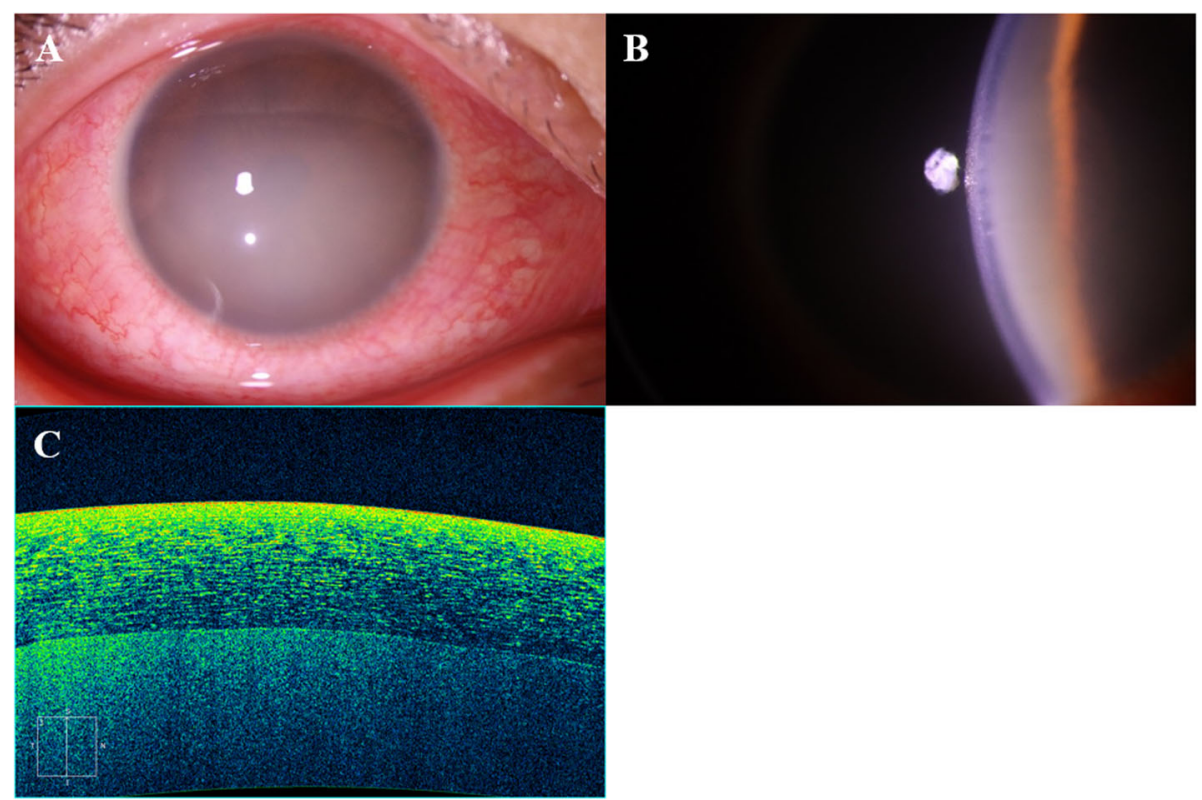

Fig. 1 a Very severe flare (milky appearance) in the anterior chamber of the right eye was observed with slit lamp biomicroscopy. And pupil margin and iris details were barely observable. There was also moderate hyperemia in the conjunctiva. $\mathbf{b}$ Inflammatory cells in the anterior chamber were hardly countable because of severe haziness. c Severe haziness in the anterior chamber because of flare was observed in optical coherence tomography. Inflammatory cells were masked by the severe flare

accompanied by severe conjunctival injection. The detailed ophthalmic examination revealed the best corrected visual acuity $20 / 60$ in the right eye and $20 / 20$ in the left eye. Severe and diffuse conjunctival hyperemia was observed in the right eye with intraocular pressure of $16 \mathrm{mmHg}$. (Fig. 1a) Very severe flare in the anterior chamber was observed with slit lamp biomicroscopy. (Fig. 1b). It was impossible to observe or count inflammatory cells in the anterior chamber because of severe haziness. (Fig. 1c). The pupil margin and iris details were
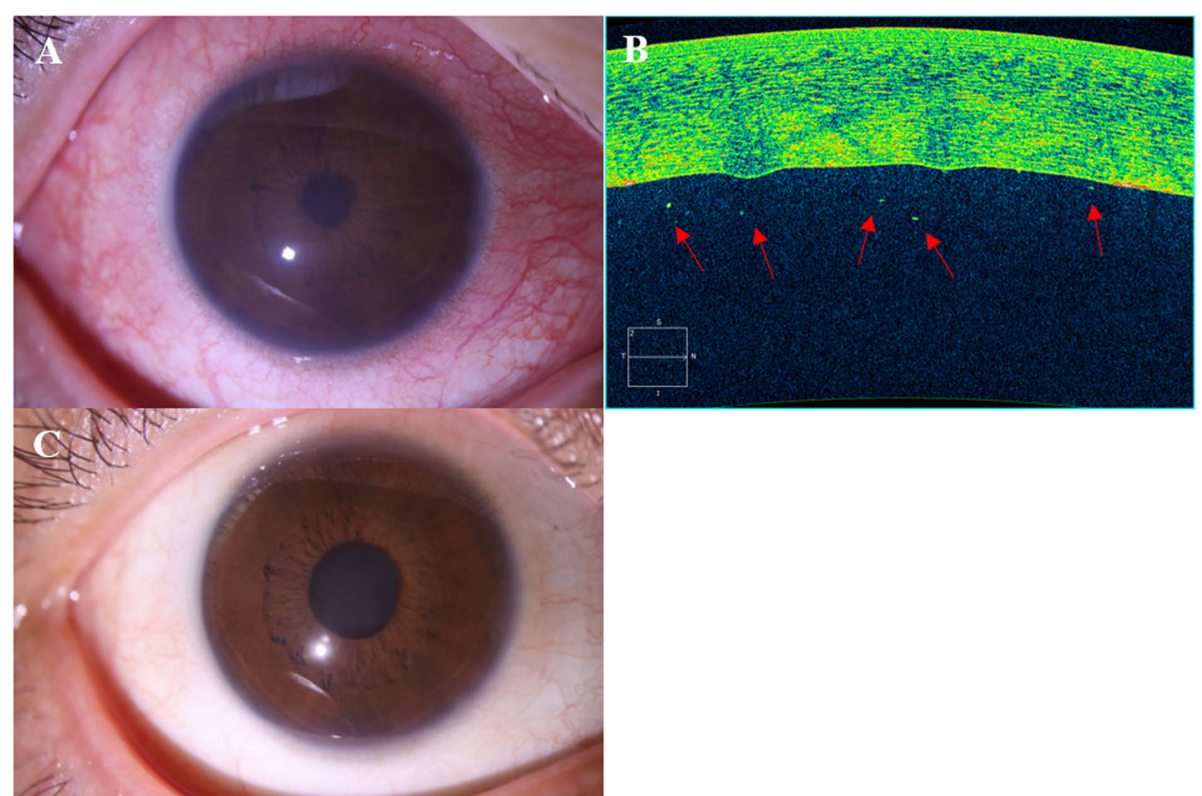

Fig. 2 a After one day of treatment, the flare reaction decreased significantly in the right eye. Pupil margin and iris details were visible with mild conjunctival hyperemia. $\mathbf{b}$ Inflammatory cells (red arrows) were visible with the significant resolution of the flare in the anterior segment optical coherence tomography. c After 1 month of treatment, inflammation was completely resolved in the right eye 
barely observable. Optic disc and retinal vessels were faintly visible. Optical coherence tomographic image of the anterior segment showed diffuse and moderate increase of corneal thickness and diffuse high signals occupying anterior chamber. He started oral prednisolone 20 mg daily with topical $1 \%$ prednisolone acetate (Pred Forte, Allergan, CA) every $2 \mathrm{~h}$ and $1 \%$ topical cyclopentolate (Cyclogyl, Alcon, TX) three times daily. Systemic work-up was performed including blood and urine samplings and chest X-ray to exclude etiologies including autoimmune and non-autoimmune diseases. The next day, the flare reaction of the right eye decreased significantly and inflammatory cells in the anterior chamber were visible. (Fig. 2a\&b). Detailed fundus examination revealed no inflammatory signs on the retina and ciliary body. Later, blood test revealed positive HLA B27 and autoantibodies against lupus anticoagulant with mild elevation of $C$ reactive protein. There were no signs for ankylosing spondylitis. Continued treatment and tapering of topical $1 \%$ prednisolone acetate for 4 weeks led to the complete resolution of the anterior uveitis. (Fig. 2c).

\section{Discussion and conclusions}

According to the clinical features and blood test, the current case was diagnosed as HLA-B27 associated AAU. The prevalence of HLA-B27 varies widely between ethnic population and was reported as $7-8 \%$ in Caucasian, $4 \%$ in African, $2-9 \%$ in Chinese and $14-16 \%$ in Northern Scandinavian [9]. Frequency of HLA-B27 in Korean population was reported as 4.6-6.3\% [10]. HLAB27 is strongly associated with anterior uveitis and ankylosing spondylitis. The prevalence of HLA-B27 in AAU and in ankylosing spondylitis is thought to be up to 50 and $90 \%$, respectively [9]. In addition, reactive arthritis, psoriatic arthritis and inflammatory bowel diseases are also associated with HLA- B27 and these conditions should also be considered as differential diagnosis in this case [9]. Herpetic anterior uveitis can be another differential diagnosis, although iris atrophy, posterior synechiae and elevated intraocular pressure are more common clinical features associated with Herpesviridae caused anterior uveitis [11].

The exact mechanism why HLA- B27 predisposes various immunologic diseases has not been fully elucidated. However, one hypothesis is that HLA-B27 encodes a number of alleles with polymorphic differences that primarily change amino acids in the antigen-binding cleft and induce a different antigen presentation which can trigger CD8 T cell proliferation [9]. Another hypothesis is that HLA-B27 has unique ability to bind some intracellular bacterial antigens such as Yersinia, Shigella, Salmonella and Chlamydia and can trigger autoimmune response [12].
The clinical characteristics of HLA-B27 associated AAU include mainly unilateral involvement, male preponderance, younger age of onset and severe fibrin reaction $[13,14]$. A recent literature-based meta-analysis reported that inflammation signs such as fibrinous reaction and hypopyon were more severe in HLA-B27 positive AAU compared to HLA-B27 negative AAU [13]. Among HLA-B27 positive AAU patients, the comorbidity of ankylosing spondylitis was associated with a higher percentage of fibrinous exudation, synechiae and secondary glaucoma as compared with ankylosing spondylitis negative cases [15]. The recurrence of HLA-B27 associated AAU is high with the average frequency of annual recurrence approximately $0.8-1.1 \%[14,16]$.

The prompt initiation of systemic steroid resulted in the rapid resolution of the flare reaction with visual acuity recovery in our case. Herbort et al. [8] reported that patients with HLA-B27-associated AAU had marked elevations of flare with the sudden onset of disease and that flare decreased rapidly to normal levels with treatment. The flare was more severe in our case, but the course of the disease was similar. However, it is noteworthy that the treatment with both topical and systemic steroids in the management of a unilateral acute anterior uveitis is controversial because it can aggravate infection-related uveitis. Therefore, careful decision making is essential. Peribulbar or subtenon steroid injection can also be useful alternative treatments [17].

The prognosis of HLA B27-associated uveitis is usually favorable. But, the final visual acuity was worse in HLAB27 positive AAU than in HLA-B27 negative AAU. And studies have reported up to $11 \%$ of patients becoming legally blind in the affected eyes [18].

In summary, we experienced HLA-B27 AAU with the feature of a very severe flare reaction. Although the flare reaction was extraordinary, conventional uveitis treatment was successful to acquire the complete resolution of the inflammation.

\section{Supplementary information}

Supplementary information accompanies this paper at https://doi.org/10. 1186/s12886-020-01472-3.

Additional file 1 : Supplement Figure 1. Slit-lamp image of the right eye at 1 month after the treatment. Iris detail is clearly observed and mild cataract is visible. The anterior chamber is clear without any significant inflammatory cells.

Abbreviations

AAU: Acute anterior uveitis; HLA: Human leukocyte antigen

Acknowledgements

Not applicable.

Authors' contributions

JIK and CYP were responsible for the conception and design of the study. JIK and CYP acquired the data. JIK and CYP analyzed and interpreted the data. 
JIK and CYP wrote the draft. JIK and CYP revised the manuscript critically. All authors have read and approved the final manuscript.

\section{Funding}

The study design, data collection and writing paper are partially supported by a grant from the Korea Health Technology R\&D Project through the Korea Health Industry Development Institute (KHIDI), funded by the Ministry of Health \& Welfare, Republic of Korea (Grant number: HI-15C1653).

\section{Availability of data and materials}

All data are available upon request to the corresponding author at oph0112 @gmail.com.

\section{Ethics approval and consent to participate}

This study followed the tenets of the Declaration of Helsinki and was approved by the Institutional Review Board of Dongguk University, Ilsan Hospital, Goyang, South Korea (IRB no. 2020-01-001).

\section{Consent for publication}

We obtained written informed consent to publish the case report and any accompanying images from the patient.

\section{Competing interests}

The authors declare that they have no competing interests except that the author, Choul Yong Park, serves as a member of editorial board of BMC Ophthalmology.

Received: 30 January 2020 Accepted: 18 May 2020

Published online: 24 May 2020

\section{References}

1. Holland GN. A reconsideration of anterior chamber flare and its clinical relevance for children with chronic anterior uveitis (an American ophthalmological society thesis). Trans Am Ophthalmol Soc. 2007;105:34464.

2. Gonzales CA, Ladas JG, Davis JL, Feuer WJ, Holland GN. Relationships between laser flare photometry values and complications of uveitis. Arch Ophthalmol. 2001;119(12):1763-9.

3. Ladas JG, Wheeler NC, Morhun PJ, Rimmer SO, Holland GN. Laser flare-cell photometry: methodology and clinical applications. Surv Ophthalmol. 2005; 50(1):27-47.

4. Herbort CP, Tugal-Tutkun I. The importance of quantitative measurement methods for uveitis: laser flare photometry endorsed in Europe while neglected in Japan where the technology measuring quantitatively intraocular inflammation was developed. Int Ophthalmol. 2017;37(3):469-73.

5. Guex-Crosier Y, Pittet N, Herbort CP. Evaluation of laser flare-cell photometry in the appraisal and management of intraocular inflammation in uveitis. Ophthalmology. 1994;101(4):728-35.

6. Tugal-Tutkun I, Cingu K, Kir N, Yeniad B, Urgancioglu M, Gul A. Use of laser flare-cell photometry to quantify intraocular inflammation in patients with Behcet uveitis. Graefe's Archive Clin Exp Ophthalmol. 2008;246(8):1169-77.

7. Agarwal A, Joshi D, Katoch D, Aggarwal K, Singh R, Gupta V. Application of laser flare photometry in the quantification of blood-aqueous barrie breakdown after micro-incision vitrectomy. Ocul Immunol Inflamm. 2019; 27(4):651-7.

8. Herbort CP, Guex-Crosier Y, de Ancos E, Pittet N. Use of laser flare photometry to assess and monitor inflammation in uveitis. Ophthalmology. 1997;104(1):64-71 discussion 71-62.

9. Kopplin $L$, Mount G, Suhler EB. Review for disease of the year: epidemiology of HLA-B27 associated ocular disorders. Ocul Immunol Inflamm. 2016;24(4):470-5.

10. Whang DH, Yang YS, Hong HK. Allele and haplotype frequencies of human leukocyte antigen-A, $-B$, and -DR loci in Koreans: DNA typing of 1,500 cord blood units. Korean J Lab Med. 2008:28(6):465-74.

11. Neumann R, Barequet $D$, Rosenblatt $A$, Amer $R$, Ben-Arie-Weintrob $Y$, Hareuveni-Blum T, Vishnevskia-Dai V, Raskin E, Blumenfeld O, Shulman S, et al. Herpetic anterior uveitis - analysis of presumed and PCR proven cases. Ocul Immunol Inflamm. 2019:27(2):211-8.

12. Bowness P. Hla-B27. Annu Rev Immunol. 2015;33:29-48.
13. D'Ambrosio EM, La Cava M, Tortorella P, Gharbiya M, Campanella M, lannetti L. Clinical features and complications of the HLA-B27-associated acute anterior uveitis: a Metanalysis. Semin Ophthalmol. 2017;32(6):689-701.

14. Tay-Kearney ML, Schwam BL, Lowder C, Dunn JP, Meisler DM, Vitale S, Jabs DA. Clinical features and associated systemic diseases of HLA-B27 uveitis. Am J Ophthalmol. 1996;121(1):47-56.

15. Yang P, Wan W, Du L, Zhou Q, Qi J, Liang L, Wang C, Wu L, Kijlstra A. Clinical features of HLA-B27-positive acute anterior uveitis with or without ankylosing spondylitis in a Chinese cohort. Br J Ophthalmol. 2018;102(2): 215-9.

16. Monnet D, Breban M, Hudry C, Dougados M, Brezin AP. Ophthalmic findings and frequency of extraocular manifestations in patients with HLA-B27 uveitis: a study of 175 cases. Ophthalmology. 2004;111(4):802-9.

17. Valdes LM, Sobrin L. Uveitis therapy: the corticosteroid options. Drugs. 2020. https://doi.org/10.1007/s40265-020-01314-y. [Epub ahead of print].

18. Power WJ, FRCS., FRCOphth, Rodriguez A, Pedroza-Seres M, Foster CS. Outcomes in Anterior Uveitis Associated with the HLA-B27 Haplotype. Ophthalmology. 1998;105:1646-51

\section{Publisher's Note}

Springer Nature remains neutral with regard to jurisdictional claims in published maps and institutional affiliations.
Ready to submit your research? Choose BMC and benefit from:

- fast, convenient online submission

- thorough peer review by experienced researchers in your field

- rapid publication on acceptance

- support for research data, including large and complex data types

- gold Open Access which fosters wider collaboration and increased citations

- maximum visibility for your research: over $100 \mathrm{M}$ website views per year

At BMC, research is always in progress.

Learn more biomedcentral.com/submission 